\title{
Changing Dynamics of India-GCC Relations under Modi Government: Prospects and Challenges
}

\author{
Dr. Vikash Kumar* \\ Research Scholar Centre for West Asian Studies School of International Studies Jawaharlal Nehru University,
} New Delhi

*Corresponding Author: Dr. Vikash Kumar, Research Scholar Centre for West Asian Studies School of International Studies Jawaharlal Nehru University, New Delhi

\begin{abstract}
India is connected with Gulf region through civilizational bonds, maritime trade, cultural linkage and political connection. For India the Gulf constitutes are 'immediate neighbourhood' because it separated by only Arabian Sea. The Gulf Cooperation Council (GCC) is a collective entity. As a collective entity the GCC has been increasingly determining the trade, political and strategic policies of its member states. Therefore, the GCC is tremendous significance for India. India has vital stake in the stability, maritime security and economic well being of the Gulf countries. India under Modi government is moving ahead rapidly in this region with economic, energy and strategic cooperation. The GCC has emerged as major economic and strategic partner of India. The GCC's substantial hydrocarbon reserves are of utmost importance for India's energy security. In this paper, an attempt has been made to explore India's potential for economic, energy and political cooperation with GCC countries. India enjoys traditionally greater friendship and deeper cooperation with the GCC. The GCC countries host to a large Indian diaspora. India's civilizational ties with GCC states, coupled with increasing imports of hydrocarbon, growing bilateral investment and presence of 8 million Indian diasporas in the region. India's economic linkage with the Gulf countries have increased steadily, especially due to economic sanction on Iran. During 2018-19 India's exports to GCC were US\$60 billion. The bilateral two-way trade during 2018-19 was US \$200 billion. From the strategic point of view, India and the GCC share the desire for regional stability and security in the region. The common maritime trade opportunities and security concerns of India and the GCC create deeper cooperation. The GCC countries are going through important changes and transformation in the post-Arab spring. Therefore, India needs to understand the process of changes and transformation. This study aims to analyse and examine the prospects and challenges for India in the Gulf region.
\end{abstract}

Keywords: Gulf Region, National Interest, Civilizational Bonds, Indian Diaspora, Remittances, Modi Government, Energy Security, Political Stability, Security Concern

\section{INTRODUCTION}

India's engagement with the Gulf countries is rooted in its enduring maritime trade, historical, cultural and civilizational ties with the region. Even in the $21^{\text {st }}$ century, the Gulf region has been a major economic and strategic partner with India as evidenced by the significant Indian diaspora in the region. After India's 'Look East' foreign policy strategy, the country has added a new approach with 'Look West' under the UPA government. Under Modi government India added another new approach 'Link West policy' for deeper cooperation and friendship with this region. Through this new approach India is pursuing effective engagement with the Gulf countries. Back to back visits to the Gulf region by prime minister Narendra Modi underline India's growing engagement with the Gulf region, which has become vital for India's energy, political, economic and strategic interest.

The Gulf region hosts eight million Indians earning remittances of around $\$ 50$ billion annually. This paper investigates India's strategic relations with the members of the GCC. It argues that India-GCC ties will be among the most important relationships for both sides in the coming decades. The emergence of several factors is forcing Modi government to consider the strategic aspects of those ties. India's dependency on Gulf hydrocarbon has risen after US's economic sanction on Iran and in 2019 over half of India's oil and gas imports came from GCC countries. 


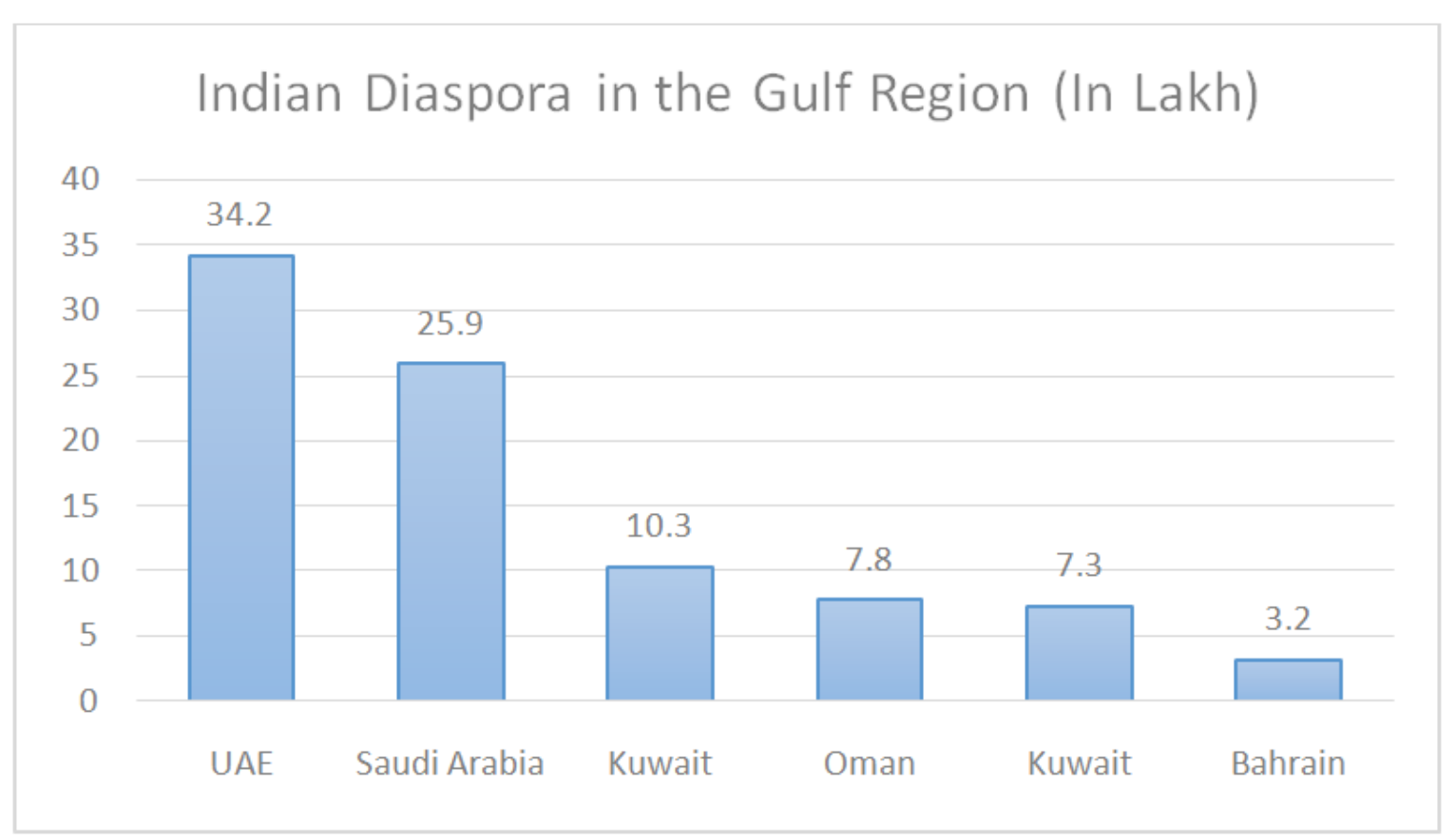

Fig1.1. Indian Diaspora in the Gulf Region

(Source: Ministry of External Affairs, Government of India)

India's expanding regional aspirations across the Indian Ocean and Atlantic Ocean are also a factor. India believes the Gulf region and South Asia as mutually interactive and interrelated regions (Alam and Ahmed 2017, p. 1). Therefore, Modi government has increased its focus on the Gulf region. The increase in India's world tradegives new impetus for cooperation with the strategically located GCC states. Furthermore, India's civilizational ties to the region motivate Modi government to strengthen current ones. The paper analyzes these factors, especially Modi government's desire to accelerate India's rise as a global power; India's expanding aspirations in the West Asian region; instability in West Asia; increasing multi-polarity in the Gulf region; and growing interest among GCC states to reach out to new partners. The paper goes on to outline India's advantages, constraints, and competition in responding to these developments.

\section{Changing DyNAMiCs 0F INDIA-GCC RELATIONS}

India and the Gulf countries have civilizational relations. Since ancient time Indians and people from Gulf countries have frequently travelled to each other's countries for trade, cultural purposes and other activities. Indian presence in the Gulf region is civilizational and has developed into a vibrant relationship over the years (Pradhan 2010, p. 1). The Gulf's importance for India had steadily risen in the Post-Cold War period. Formers prime ministers P.V. Narasimha Rao, Atal Bihari Vajpayee and Manmohan Singh urged India to look beyond its immediate neighbourhood. Modi government is the first one to pay sustained high-level political attention to the region. Prime minister Modi has visited frequently to the Gulf countries since 2015.

Prime minister Modi has been honoured with many civilian orders by the Gulf countries. Prime Minister Narendra Modi does seem to be prioritizing the Gulf, coining 'Look West and Link West' as a new policy and making visits to Gulf countries. The emergence of India as the fastest growing economy of the world, its stable political system, its overwhelmingly dependence on the imports of natural energy to keep fuelling its economy and growing strategic importance of India for GCC are some of the factors that have made New Delhi a strategically significant partner in the 'Look East Policy' of GCC (Sheikh 2019, p. 888)

Modi government is trying to boost these relations, India can tap its significant soft power, stemming from its benign image in the region. Additionally, the size and importance of India's diaspora gives leverage, and India's good relations with the Gulf countries primary backer, facilitates cooperation between them. The discovery of hydrocarbon (oil, gas etc.) in the Gulf countries resulted in large scale import of manpower from India. Therefore, Indian workers started migrating to these countries in search of employment. Today Indians are presence in these countries in large number. By sending their earnings back to their country in the form of remittances the Indian expatriate workers have 
crucial role in the progress and development of the Indian economy (Azhar 2016, p. 102). The remittances are also crucial for the management of foreign exchange and balance of payments in India. In this regard, present government of India has frequently taken steps to enhance the mobilization of remittances from the Gulf region.

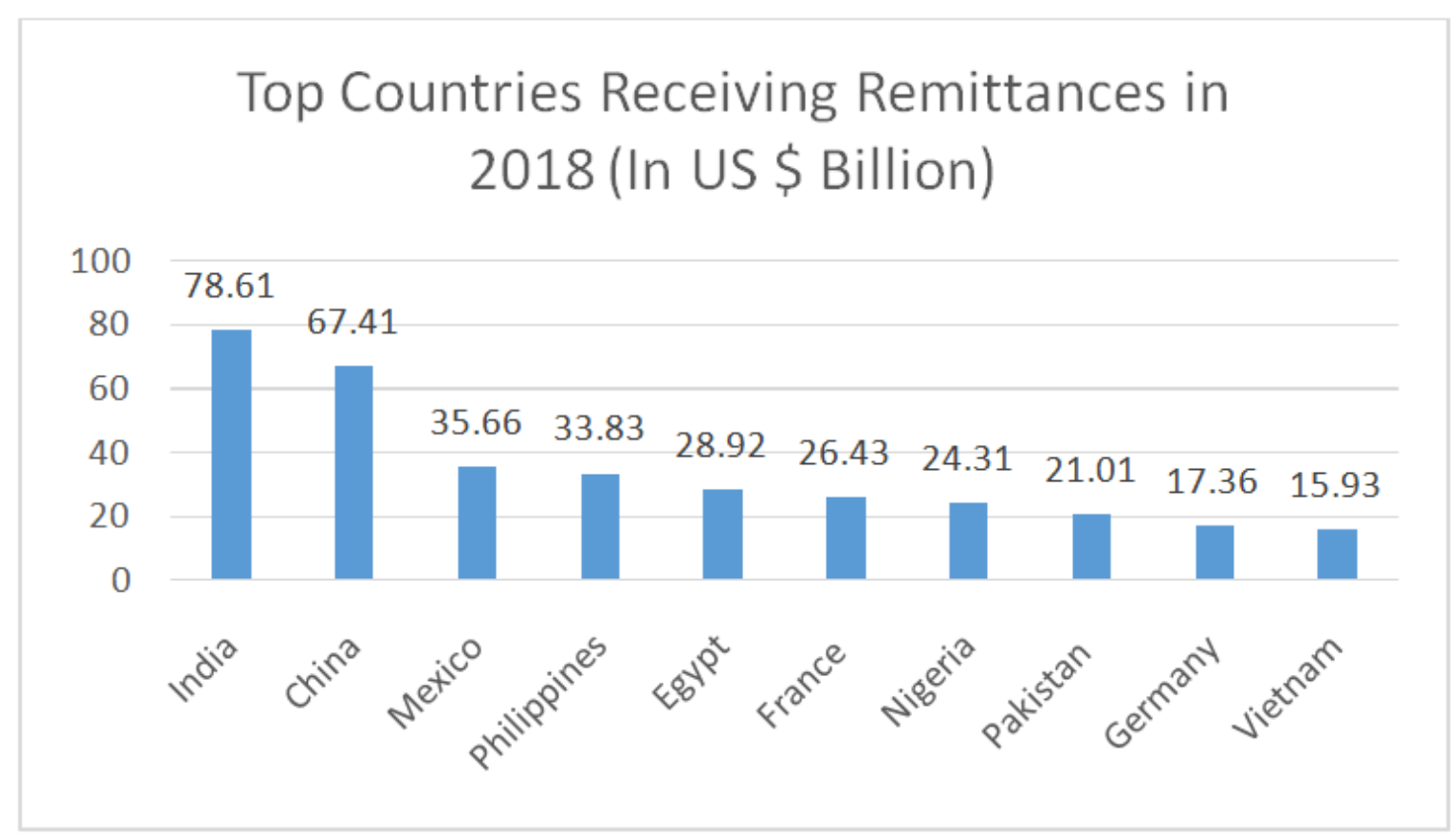

Fig1.2. Top Countries Receiving Remittances in 2018

(Source: Public Information Bureau, Government of India)

In essence, Indian diaspora in the Gulf region has played a pivotal role in the transformation of IndiaGCC relations. The Gulf's strategic and economic engagement with India intensified in the changing global order. India's economic growth also has change the perceptions of the Gulf countries. Though economic relations remain the backbone of the relationship, India and the GCC have been looking for new areas of cooperation and are trying to strengthen their political and strategic ties (Dahiya, 2014, p. 12).

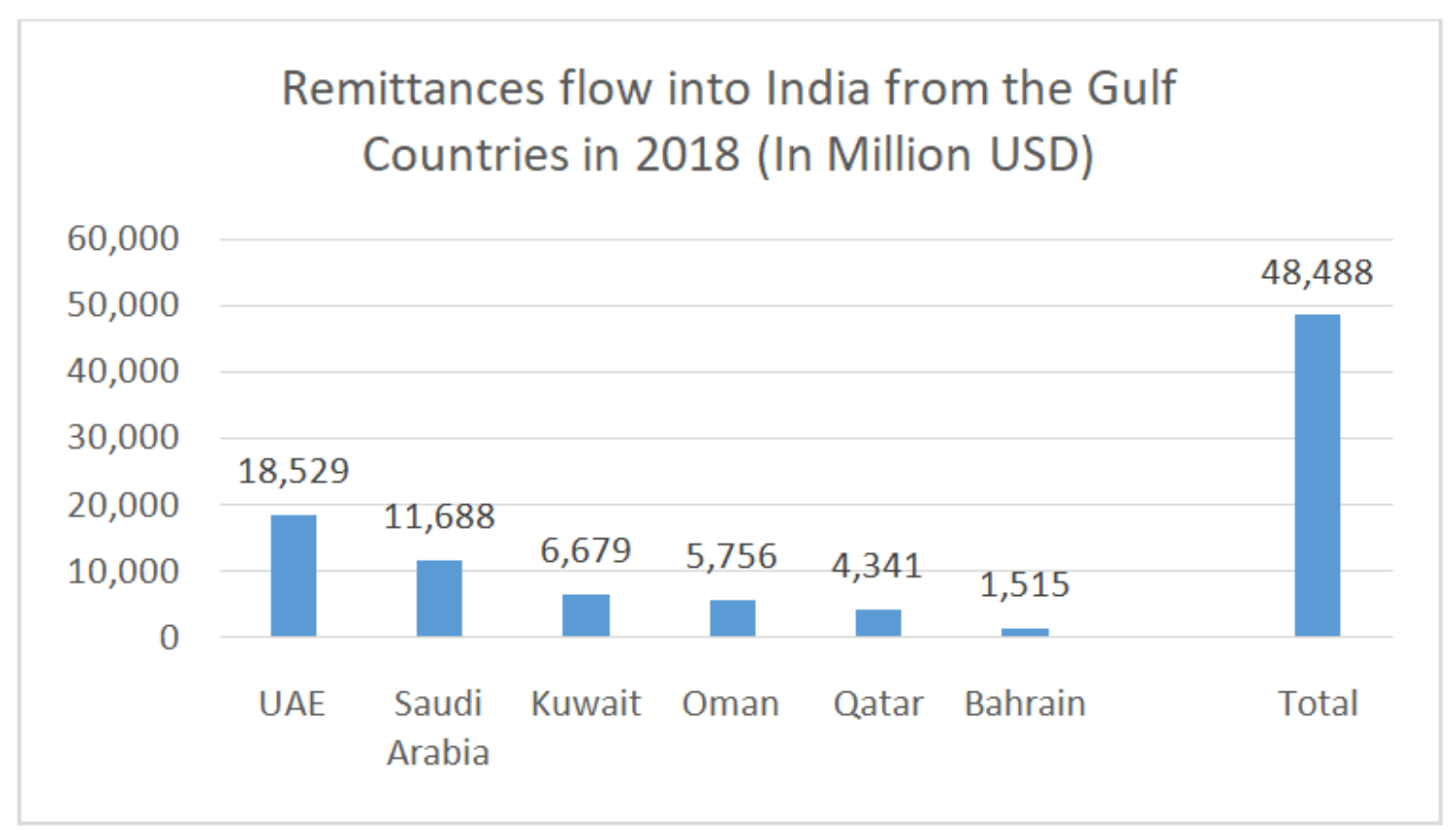

Fig1.3. Remittances inflow in India from the GCC countries

(Source: Public information Bureau, Government of India)

The economic relations between India and the GCC countries are backbone of the relationship (Pradhan 2018, p. 411). The GCC countries are India's largest trading partner. During 2018-19 the 
United Arab Emirates (UAE) and Saudi Arabia are India's third and fourth largest trading partners respectively. The total bilateral trade between India and the GCC countries are estimated US \$121 billion during 2018-19. The United Arab Emirates (UAE) is major source of foreign direct investment (FDI) for India. Both countries are signed agreement with India to invest US \$ 100 billion in the areas of energy, refining, petrochemicals, minerals and mining (Saba and Shahid 2019, p. 4). Recently Aramco acquired 20\% stake in the Reliance's Jamnagar refinery. India's ONGC Videsh has acquired a 10 per cent stake in the offshore oil in Abu Dhabi for US \$ 600 million. Through collaboration with Indian firms, the GCC countries have invested in infrastructure in India.

In addition to economic cooperation, Indian government has made strenuous efforts to build better political cooperation. Through 'Link West Policy' Modi government has brought the GCC closer to India. As a prime minister Narendra Modi has visited frequently to the GCC countries. Today, the relationship between India and the GCC countries is based on camaraderie and respect (Chaudhury 2016, p. 227). India, in the recent past, has signed many security and political agreement with the GCC countries. For strengthen the security cooperation India and the GCC countries have hosted numerous bilateral defence exercises. India and Oman hold annual bilateral exercises with three wings of armed forces. Further, Indian navy uses Oman's Duqm SEZ port which is one of the largest deepsea ports in the Indian Ocean (Upadhyaya 2019, p. 29). India has a bilateral naval as well as an air force exercise with the UAE, Bahrain and Saudi Arabia.

\section{Challenges AND Prospects For India}

India also faces competition in boosting its ties with GCC countries, most notably from China and Pakistan. China has significant ties with GCC countries and Iranwhich is major obstacle to India. Pakistan remains India's chief rival, enjoys close ties with GCC states, and is opposed to increased Indian presence in the Gulf (Gupta and Bagader 2018, p. 3). India needs to counter Pakistan's strategy while engaging with the region. Most countries in the Gulf region has affection on Pakistan. Pakistan has always uses Muslim card in his foreign policy. Pakistan wants to counter India's growing presence in the Gulf region through OIC and other strategies. After India, Pakistani diaspora is in large number in this region.

Apart from Pakistan, China is another challenge for India's national interests in this region. China is economically strong and has invested 200 US \$ billions in many areas in this region (Fulton 2017, p. 1). The United Arab Emirates is good friend of China. China's investment in the Gulf refineries have affected India's energy interests. China has also replaced India from Iran's Chabahar and rail project. Therefore, India needs an integrated regional strategy to secure its national interests in this region.

As India's interests expand, maintaining its values, neutrality, and strategic autonomy may be increasingly difficult. In addition to India and the Gulf countries, others are also recalibrating their policies to the evolving power shifts in this region. Recently, a trilateral maritime exercise was held between Iran, Russia and China in the Persian Gulf and Arabian Sea. These developments suggest a steady increase in the density of external actors seeking to shape the geopolitics of the Gulf region (Press Information Bureau 2019, p.1).

Looking forward, Modi government's commitment to boosting its relations with the Gulf states will lead to stronger India-GCC relations. However, India's relations with Israel is growing. In the longterm, GCC countries could encourage India to play a greater role in stabilizing West Asia and learn from India's experience in strengthening internal stability and institutions (Ministry of External Affairs 2020, p. 2). Lastly, the shifting energy landscape should present additional opportunities for cooperation using Indian human resources and GCC capital.

\section{CONCLUSION}

Under Modi government India has established very close economic and political relations with the Gulf countries. India's relations with the Gulf countries have never been as good as they are under Modi government. The rising of economic growth is marked by growing volumes of energy imports into India and prospect of substantive investments from the Gulf region into the Indian market. The number of India migrant workers in the Gulf region stands at more than 8 million. Today, the Gulf is among India's top trading partners. The Gulf countries are important source source of India's oil and gas imports and important destination for manpower export. India is the largest remittance earning country in the world. More than half of India's remittance earnings of US \$ 83 billion come from the 
Gulf region. Since 2015 a high level engagement between India and the Gulf countries are going on. Prime minister Modi has frequently visited frequently to the Gulf region and there has been a steady stream of head of states visiting India. The expansion of economic and political engagement has been matched by the growing security cooperation, especially on counter ISIS terrorism. India needs dehyphenation strategy to secure its ever rising stakes in the Gulf region region.

\section{REFERENCES}

[1] Alam, Imran and Ahmed, Shahid (2017), "Prospects of India-GCC Trade Relations: An Empirical Investigation", Foreign Trade Review, Vol. 1, No. 1, pp. 1-14.

[2] Azhar, Muhammad (2016), "Indian Migrant Workers in the GCC countries", Diaspora Studies, Vol. 9, No. 2, pp. 100-111.

[3] Chaudhury, Rahul Roy (2016), "India: Gulf Security Partner in Waiting”, Middle Eastern Security, Vol. 54, No. 1, pp. 225-246.

[4] Embassy of India, Riyadh Saudi Arabia (2020), India-GCC Relations, website: https://www.eoiriyadh. gov.in/page/india-gcc-relations/

[5] Fulton, Jonathan (2017), "The GCC Countries and China's Belt and Road Initiative: Curbing Their Enthusiasm?", Middle East Institute, Vol. 1, No. 1, pp. 1-16.

[6] Gupta, Ranjit and Bagader, Abu Backer (2018), "India and the gulf: What Next?", Gulf Research Centre Cambridge: University of Cambridge, Vol. 6, No. 1, pp. 1-10.

[7] Ismail, Saba and Ahmed, Shahid (2019), "Economic effects of Tariff Liberalization of Prospective IndiaGCC FTA: A Computable General Equilibrium Analysis", Foreign Trade Review, Vol.1, No. 1, pp. 1-12.

[8] Ministry of External Affairs (2020), India-UAE Joint Meeting, website: https://www.mea.gov.in/pressr eleases.htm?dtl/32900/external+affairs+minister+and+foreign+minister+of+uae+cochair+13th+indiauae $+j$ $\mathrm{cm}$

[9] Pradhan, Prashanta Kumar (2010), "India and the Gulf Cooperation Council: Time to Look Beyond Business", Strategic Analysis, Vol. 34, No. 3, pp. 409-419.

[10] Pradhan, Samir (2010), "India and the Gulf Cooperation Council (GCC): An Economic and Political Perspective", Strategic Analysis, Vol. 34, No. 1, pp. 93-103.

[11] Press Information Bureau (2018), India-UAE Bilateral Investments, website: https://pib.gov.in/Press ReleasePage. aspx?PRID=1520423

[12] Press Information Bureau (2019), Foreign Minister of UAE calls on PM Modi, Website: https://pib.gov.in /PressReleasePage.aspx?PRID=1578050

[13] Press Information Bureau (2019), Strategic Partnership Council Agreement with Saudi Arabia, Website: https://pib.gov.in/PressReleasePage.aspx?PRID=1589413

[14] Sheikh, Shabir Rahman (2019), "India-GCC Relations: Moving Beyond Oil”, International Journal of Research and Analytical Review, Vol. 6, No. 2, pp. 887-891.

[15] Upadhyaya, Shishir (2019), "India's Maritime Security Relations with Gulf Cooperation Council Countries-Prospects Amid Rising Chinese Influence", Maritime Affairs, Vol. 15, No. 1, $27-40$.

Citation: Dr. Vikash Kumar. "Changing Dynamics of India-GCC Relations under Modi Government: Prospects and Challenges" International Journal of Political Science (IJPS), vol 6, no.3, 2020, pp. 27-31. doi: https://doi.org/10.20431/2454-9452.0603004.

Copyright: () 2020 Authors. This is an open-access article distributed under the terms of the Creative Commons Attribution License, which permits unrestricted use, distribution, and reproduction in any medium, provided the original author and source are credited. 